OPEN ACCESS

Edited by:

Xiaofei Shang,

Chinese Academy of Agricultural

Sciences, China

Reviewed by:

Bashir A. Lone,

University of Kashmir, India

Craig Robert Reinemeyer

East Tennessee Clinical Research,

Inc., United States

*Correspondence: José Alberto Rosado-Aguilar

ja.rosado@correo.uady.mx

Rocío Borges-Argáez

rborges@cicy.mx

Specialty section:

This article was submitted to

Parasitology,

a section of the journal

Frontiers in Veterinary Science

Received: 23 May 2020

Accepted: 17 August 2020

Published: 23 September 2020

Citation:

Flota-Burgos GJ, Rosado-Aguilar JA, Rodríguez-Vivas Rl, Borges-Argáez R, Martínez-Ortiz-de-Montellano $C$ and

Gamboa-Angulo M (2020) Anthelmintic Activity of Extracts and Active Compounds From Diospyros anisandra on Ancylostoma caninum, Haemonchus placei and Cyathostomins.

Front. Vet. Sci. 7:565103. doi: 10.3389/fvets.2020.565103

\section{Anthelmintic Activity of Extracts and Active Compounds From Diospyros anisandra on Ancylostoma caninum, Haemonchus placei and Cyathostomins}

\author{
Gabriela Janett Flota-Burgos ${ }^{1}$, José Alberto Rosado-Aguilar ${ }^{1 *}$, \\ Roger Iván Rodríguez-Vivas ${ }^{1}$, Rocío Borges-Argáez ${ }^{2 *}$, \\ Cintli Martínez-Ortiz-de-Montellano ${ }^{3}$ and Marcela Gamboa-Angulo ${ }^{2}$ \\ ' Departamento de Salud Animal, Facultad de Medicina Veterinaria y Zootecnia, Universidad Autónoma de Yucatán, Mérida, \\ Mexico, ${ }^{2}$ Unidad de Biotecnología, Centro de Investigación Cientifica de Yucatán A.C., Mérida, Mexico, ${ }^{3}$ Departamento de \\ Parasitología, Universidad Nacional Autónoma de México, Ciudad de México, Mexico
}

The present study aimed to evaluate the anthelmintic activity of leaf and bark extracts of Diospyros anisandra collected during different seasons and their major constituents on eggs of Ancylostoma caninum, Haemonchus placei, and cyathostomins. Specifically, the eclosion inhibition of the methanolic extracts of the leaves and bark of $D$. anisandra collected during the dry and rainy seasons $(600-37.5 \mu \mathrm{g} / \mathrm{ml})$ were evaluated in addition to the fractions, sub-fractions (300-37.5 $\mathrm{g} / \mathrm{ml})$ and active major constituents (150-2.3 $\mu \mathrm{g} / \mathrm{ml})$. The rainy season bark extract had the highest percentage of eclosion inhibition (PEl) against the evaluated nematodes ( $\geq 90 \%$ at $75 \mu \mathrm{g} / \mathrm{ml})$ along with high ovicidal activity (90.0 to $93.4 \%$ at $75 \mu \mathrm{g} / \mathrm{ml})$. The purification of the rainy season bark extract showed that its biological activity came from the non-polar $n$-hexane fraction ( $\geq 93 \%$ at $75 \mu \mathrm{g} / \mathrm{ml}$ ). The bioguided fractionation pointed to sub-fraction 5 as having the highest anthelmintic activity against the three evaluated genera of nematodes (PEI $\geq 93 \%$ at $37.5 \mu \mathrm{g} / \mathrm{ml}$ ). Gas chromatography and mass spectrometry revealed that the major constituent in sub-fraction 5 was plumbagin. Upon evaluation, plumbagin was confirmed to be responsible for the anthelmintic activity of $D$. anisandra, with a $P E I \geq 90 \%$ at $2.3 \mu \mathrm{g} / \mathrm{ml}$ on the three evaluated nematodes. Additionally, the compounds betulin and lupeol in the bark of $D$. anisandra were evaluated but presented low anthelmintic activity (PEI $\leq 5.3 \%$ at $2.3 \mu \mathrm{g} / \mathrm{ml})$. In conclusion, the rainy season bark extract of $D$. anisandra exerts a high ovicidal activity against the eggs of the three studied nematodes. Plumbagin is the active compound responsible for this activity and represents a potential alternative for the control of different genera of gastrointestinal nematodes given the current scenario of anthelmintic resistance.

Keywords: active compounds, bioguided fractionation, gastrointestinal nematodes, plant extracts, plumbagin 


\section{INTRODUCTION}

Gastrointestinal nematodes (GINs) are a serious threat to the health and well-being of domestic animals and negatively affect the economy of animal production. Also, they can negatively affect public health because of their zoonotic potential. Some examples of GINs include Ancylostoma caninum, Haemonchus placei and cyathostomins, which are the most prevalent and pathogenic in dogs, bovines and horses, respectively (1-4).

Traditionally, the control of GINs has been based on the intensive administration of anthelmintic drugs. However, this has generated anthelmintic resistance, mainly to benzimidazoles and macrocyclic lactones. There are also reports of Ancylostoma caninum resistance to pyrantel, Haemonchus placei resistance to salicylanilides and imidazothiazoles and cyathostomin resistance to tetrahydropyrimidines (4-7). The situation is exacerbated by multi-resistance to numerous anthelmintics, which has been documented in the aforementioned three genera (8-11).

The lack of effectiveness of current anthelmintic treatments has prompted the search for control alternatives, including the use of plant extracts with anthelmintic properties and their secondary metabolites. Plant extracts and their natural derivatives have long been used as an additional or alternative treatment to conventional chemical products and have also served as important sources of new anthelmintic molecules for the development of alternative treatments (12). Among the plants reported to have broad biological activity in the Mexican tropics is Diospyros anisandra (13-15). Arjona-Cambranes et al. (16) found that the bark extract of $D$. anisandra inhibited more than 98\% of Ancylostoma caninum eclosion (the act of hatching from the egg) in vitro at a concentration $1,200 \mu \mathrm{g} / \mathrm{ml}$ and that the leaf extract showed a similar percentage of eclosion inhibition (PEI) at triple the concentration $(3,600 \mu \mathrm{g} / \mathrm{ml})$. Thus, the bark extract of $D$. anisandra appears to exert an ovicidal effect. Another study confirmed the effects of the methanolic extract of $D$. anisandra against cyathostomin eggs, finding a PEI $>90 \%$ at a concentration of $75 \mu \mathrm{g} / \mathrm{ml}$. Specifically, two effects were noted: an ovicidal effect from using the bark extract and a larval effect using the leaf extract in which larvae failed to hatch (15).

Despite the demonstrated anthelmintic potential of $D$. anisandra in these previous studies, its extract was only evaluated in each case against one genus of nematode. The question remains as to whether $D$. anisandra extracts have a broad spectrum of action or exert effects against two or more genera of nematodes. Also, only the methanolic extracts of $D$. anisandra were evaluated without determining the active compound(s) that confers its biological activity. Hence, the objective of the present study was to evaluate the anthelmintic activity of leaf and bark extracts of $D$. anisandra collected during different seasons of the year and their major constituents on eggs of Ancylostoma caninum, Haemonchus placei, and cyathostomins.

\section{MATERIALS AND METHODS}

The present study was carried out at the Parasitology Laboratory of the Faculty of Veterinary Medicine (Facultad de Medicina Veterinaria) of the Autonomous University of Yucatán
(Universidad Autónoma de Yucatán). The region has a warm, sub-humid climate $(85.7 \%$ of the territory) characterized by a rainy (June-October) and dry (February-May) season, average annual temperature of $26^{\circ} \mathrm{C}$, relative humidity between 65 and $95 \%$ and an average annual rainfall of $902 \mathrm{~mm}$ (17).

\section{Information From Diospyros anisandra and the Collection Site}

Diospyros anisandra S. F. Blake is a quasi-endemic species of Peninsula of Yucatan, commonly known as k'aakalche ', k'ab che' or xanob che', of the Ebenacea family; It can measure up to 7 meters in height, uses vary depending on the locality, such as wood, instrument making, firewood and skin diseases such as pimples, scabies and inflammation $(18,19)$. And it is widely distributed in the Yucatan Peninsula. D. anisandra is a shrub or small tree, up to 7 meters tall, short branches, glabrous. Leaves subfasciculate at the tips of the branches, obovate, rounded and reticulous at the apex, cuneate at the base, glabrous or almost glabrous, 2 to $6 \mathrm{~cm}$ long and 1.2 to $3 \mathrm{~cm}$ wide. Axillary inflorescence, from 1 to 2 staminate flowers, hanging, pedicels from 1 to $2 \mathrm{~mm}$ long; funelform calyx, about $4 \mathrm{~mm}$ long, 4 lanceolate, acuminate lobes, and about $1.5 \mathrm{~mm}$ long; corolla urceolada, about $14 \mathrm{~mm}$ long, tube $7 \mathrm{~mm}$ long, acuminate lobes of similar length, 1 to 2 pistillate flowers. Globose fruits, about $1 \mathrm{~cm}$ in diameter, black and shiny when ripe. It blooms in February (the dry season), May, June, July, and September (the rainy season), although its fruits can be seen almost all year round with the exception of April and May.

The site of collection was the municipality of Yaxcabá, wich is located in the central-southern region of the state of Yucatan, Mexico. The geographical coordinates are $20^{\circ} 19^{\prime}$ and $20^{\circ} 49^{\prime}$ north latitude and $80^{\circ} 36^{\prime}$ and $88^{\circ} 56^{\prime}$ west longitude, with an average altitude of 29 meters above sea level. The average annual temperature is $26^{\circ} \mathrm{C}$, with an average annual rainfall of $1,118 \mathrm{~mm}$, subject to variations due to the presence of hurricanes (20). The prevailing climate is warm sub-humid (Aw) with rains in summer, where humidity decreases from south to north with record temperatures in May and the lowest in January. The annual rainfall is $1,111 \mathrm{~mm}$, with an annual relative humidity of $89 \%$. The characteristic soil types of the municipality are Cambisols. Calcisols and in low proportion Luvisols (21). The vegetation is a sub deciduous tropical forest in different stages of succession (22).

\section{Plant Extracts}

Leaves and bark of $D$. anisandra were collected in the rainy and dry season in Yaxcabá, Yucatán (for obtaining their extracts). Then, the aforementioned plant parts were separated and placed in a drying oven at $40^{\circ} \mathrm{C}$ for $48 \mathrm{~h}$. The dry plant material was ground in an electric mill to reduce the size of particles to $5 \mathrm{~mm}$. Two extractions were performed, each for $24 \mathrm{~h}$, using methanol $(\mathrm{MeOH})$ at a ratio of $30 \mathrm{ml}$ for every $25 \mathrm{~g}$ of ground plant material. After each extraction, the methanolic solvent was separated from the plant material through filter paper and deposited in glass flasks. Using a rotary evaporator (Rotavapor, Büchi ${ }^{\circledR}$ ), the solvent was eliminated under reduced pressure, 
concentrating the dry extract. The obtained products were placed in glass vials and stored at $4^{\circ} \mathrm{C}$ until use (23).

\section{Obtainment of GIN Eggs}

Feces samples were obtained from naturally infected animals. The McMaster technique was used to determine the GINs present and quantify the number of eggs per gram of feces (24). Consecutive coprocultures were carried out to morphologically identify the $\mathrm{L}_{3}$ larvae of Ancylostoma caninum (canine), Haemonchus contortus (bovine) and cyathostomins (equine) (Cyathostomum spp type G, Posteriostomum spp, Gyalocephalus capitatus Cylicoclyclus spp type B, Triodontophorus spp) (2527). Prior to processing samples for egg recovery, a centrifugal flotation of each sample was performed to ensure that eggs were in the morula stage and that larvae had not begun to form (28). The feces were macerated with purified water at a ratio of $100 \mathrm{ml}$ for every $50 \mathrm{~g}$ of feces. The resulting mixture was filtered through non-sterile gauze and deposited in 45- $\mathrm{ml}$ plastic tubes, which were centrifuged at $1,500 \mathrm{rpm}$ for $5 \mathrm{~min}$. The supernatant was discarded, and saturated sugar solution was added (density: 1.280). The mixture was homogenized in a vortex and once again centrifuged. The eggs were recovered from the superficial portion with an inoculation loop and deposited in phosphate buffer solution (PBS). Afterwards, three washes with PBS were performed, eliminating the residues of the saturated sugar solution. The concentration of recovered eggs (eggs $/ \mathrm{ml}$ ) was estimated, and the suspension was diluted to obtain a final solution of 400 eggs/ml $(15,29)$.

\section{Egg Hatch Assay}

The methanolic extracts were evaluated by hatching inhibition tests carried out according to the guidelines of the World Association for the Advancement of Veterinary Parasitology (WAAVP) (30). The evaluated concentrations were 600, 300, 150,75 , and $37.5 \mu \mathrm{g} / \mathrm{ml}$. To dilute the extracts and create a negative control, a solution of PBS $0.01 \mathrm{M}\left(\right.$ Sigma $\left.^{\circledR}\right)$ plus $5 \%$ absolute ethanol was used. Thiabendazole $(0.1 \mu \mathrm{g} / \mathrm{ml})$ was used as a positive control. Three repetitions were performed for each evaluated concentration. The extracts were diluted to the aforementioned concentrations in an ultrasonic bath (Branson ${ }^{\circledR}$ ). Culture plates with 24 wells were used; in each, $0.5 \mathrm{ml}$ of solution containing eggs (200 eggs approximately) was deposited in addition to 0.5 of diluted extract for a total volume of $1 \mathrm{ml}$ in each well. Then, the plates were incubated in a bacteriological oven at $28^{\circ} \mathrm{C}$ for $48 \mathrm{~h}$. At following, Lugol solution $(20 \mu \mathrm{g})$ was added to disrupt the hatching process. The contents of each well were deposited in McMaster chambers and observed through a microscope at $10 \times$ to count the number of morulated eggs, eggs with larvae inside and hatched larvae. All plates whose negative controls obtained an eclosion percentage equal to or greater than $80 \%$ were included in the study $(15,29)$.

The PEI was calculated with the following formulas proposed by Peachey et al. (31) and Flota Burgos et al. (15):

$$
\begin{aligned}
\% \text { hatched } & =\left(\frac{L_{1}}{L_{1}+\text { eggs }}\right) \times \\
\% \text { egg hatch inhibition } & =100-\% \text { hatch }
\end{aligned}
$$

The effect of the extracts on larval development was calculated according to the formulas proposed by Vargas-Magaña et al. (28) and Flota Burgos et al. (15). Two effects were recorded: ovicidal activity (OA) for eggs that did not form larvae or eggs with $\mathrm{L}_{1}$ larvae failing eclosion (LFE) during the incubation time.

$$
\begin{aligned}
& \% O A=\left(\frac{\text { morulated eggs }}{\text { morulated eggs }+ \text { eggs containing a larva }+L_{1} \text { larvae }}\right) \times(100) \\
& \% L F E=\left(\frac{\text { eggs containing a larva }}{\text { morulated eggs }+ \text { eggs containing a larva }+L_{1} \text { larvae }}\right) \times(100)
\end{aligned}
$$

\section{Fractionation of the Crude Extract of Diospyros anisandra}

The methanolic extract of $D$. anisandra was partitioned with $n$ hexane, ethyl acetate and methanol (23). The obtained fractions ( $n$-hexane, ethyl acetate and residual methanol) were evaluated by the same eclosion inhibition assays described in section Obtainment of GIN Eggs at concentrations of 300, 150, 75, and $37.5 \mu \mathrm{g} / \mathrm{ml}$.

The partition with the highest anthelmintic activity was then sub-fractionated using a glass column $(4 \times 5 \mathrm{~cm})$ with $140 \mathrm{~g}$ of sodic bentonite. Each sub-fraction was eluted (liquid-liquid partition) with $200 \mathrm{ml}$ of $n$-hexane and then with volumes of $n$-hexane and acetone of increasing polarity (ratio of 100:0 to 0:100). Based on similar Rf values in TLC (60F254 aluminum plates coated with silica gel, Merck ${ }^{\circledR}$ ) developed with the eluent $n$-hexane: acetone $(8: 2)$ and sprayed with a solution of phosphomolybdic acid, 11 fractions were grouped (23). Each sub-fraction was evaluated by hatching inhibition tests at concentrations of $300,150,75$, and $37.5 \mu \mathrm{g} / \mathrm{ml}$.

\section{Analysis by Gas Chromatography-Mass Spectrometry}

The active sub-fraction was analyzed in a gas chromatograph (Agilent Technologies $6890 \mathrm{~N}$ ) coupled with a selective mass detector with a HP-5MS column (5\% phenyl-methylpolysiloxane, $25 \mathrm{~m} \times 0.2 \mathrm{~mm}$ internal diameter). A split injection was performed on $1 \mu \mathrm{l}$ of a $1 \%$ solution of the F5 sample at a flow rate of $1.0 \mathrm{ml} / \mathrm{min}$ (helium as the carrier gas) and column temperature of $100^{\circ} \mathrm{C}$ for $3 \mathrm{~min}$; then, the temperature was increased $10^{\circ} \mathrm{C}$ per min along a gradient until reaching a final temperature of $280^{\circ} \mathrm{C}$.

The constituents in the extract were identified by searching commercial reference libraries. The fragmentation patterns of the mass spectra were compared with those in the NIST05 libraries. The major constituent (plumbagin) was then evaluated at concentrations of $150,75,37.5,18.7,9.3$, and $2.6 \mu \mathrm{g} / \mathrm{ml}$. Additionally, the major constituents of the bark extract of $D$. anisandra, betulin and lupeol, were isolated according to the methodology reported by Uc-Cachón et al. (32) and evaluated at concentrations of 150 to $2.6 \mu \mathrm{g} / \mathrm{ml}$.

\section{Statistical Analysis}

ANOVAs (generalized linear models) were carried out to identify significant differences between the evaluated concentrations and controls with respect to the eclosion inhibition tests (StatgraPEIcs 5.1). The lethal concentrations of the evaluated extracts were 
TABLE 1 | Averages and standard deviation $( \pm$ ) of the percentages of eclosion inhibition of the methanolic extracts of Diospyros anisandra against eggs of Ancylostoma caninum, Haemonchus placei, and cyathostomins.

\begin{tabular}{|c|c|c|c|c|c|c|c|}
\hline Plant part & Concentration $(\mu \mathrm{g} / \mathrm{ml})$ & \multicolumn{2}{|c|}{ Ancylostoma caninum } & \multicolumn{2}{|c|}{ Haemonchus placei } & \multicolumn{2}{|c|}{ Cyathostomins } \\
\hline \multirow[t]{5}{*}{ Bark } & C- & $8.5(0.9)^{\mathrm{a}}$ & $8.6(2.8)$ & $1.2(1.5)^{\mathrm{a}}$ & $1.9(0.5)^{\mathrm{a}}$ & $3.4(0.8)^{\mathrm{a}}$ & $5.5(1.1)^{\mathrm{a}}$ \\
\hline & $\mathrm{C}+$ & $98.8(1.3)^{\star b}$ & $99.2(0.6)^{a}$ & $97.1(0.8)^{\star b}$ & $99.6(0.5)^{\star b}$ & $98.4(0.9)^{\star b}$ & $99.0(0.1)^{\star b}$ \\
\hline & 600 & $99.1(0.8)^{\star \mathrm{b}}$ & $97.4(3.0)^{\star b}$ & $99.0(0.4)^{\star \mathrm{b}}$ & $94.9(0.5)^{\star b}$ & $99.2(0.7)^{\star \mathrm{b}}$ & $98.0(1.0)^{\star b}$ \\
\hline & 300 & $99.1(0.7)^{\star b}$ & $97.3(0.7)^{\star b}$ & $98.0(1.8)^{\star \mathrm{b}}$ & $71.9(7.5)^{\star c}$ & $99.0(0.9)^{\star b}$ & $97.4(1.7)^{\star \mathrm{b}}$ \\
\hline & 37.5 & $40.4(5.5)^{\star c}$ & $40.9(5.2)^{\star e}$ & $62.2(2.4)^{\star e}$ & $11.3(2.0)^{\star f}$ & $97.4(1.6)^{\star b}$ & $34.5(2.0)^{\star \mathrm{e}}$ \\
\hline \multirow[t]{4}{*}{ Leaves } & $\mathrm{C}-$ & $1.0(0.5)^{\mathrm{a}}$ & $1.6(1.5)^{\mathrm{a}}$ & $1.7(0.5)^{\mathrm{a}}$ & $2.2(1.9)^{\mathrm{a}}$ & $6.4(1.6)^{\mathrm{a}}$ & $5.1(1.6)^{\mathrm{a}}$ \\
\hline & $\mathrm{C}_{+}$ & $99.0(1.7)^{\star b}$ & $99.3(1.2)^{\star b}$ & $99.1(0.8)^{\star b}$ & $99.0(0.9)^{\star b}$ & $99.0(1.5)^{\star \mathrm{b}}$ & $97.1(0.9)^{\star \mathrm{b}}$ \\
\hline & 600 & $25.9(0.4)^{\star c}$ & $5.3(0.2)^{\star \mathrm{C}}$ & $81.6(2.3)^{\star c}$ & $87.9(8.8)^{\star c}$ & $99.0(0.1)^{\star b}$ & $97.1(1.3)^{\star \mathrm{b}}$ \\
\hline & 300 & $6.7(0.9)^{\star d}$ & $3.0(0.9)^{d}$ & $61.3(1.4)^{\star d}$ & $64.2(8.6)^{\star d}$ & $98.8(1.0)^{\star b}$ & $96.0(1.9)^{\star \mathrm{b}}$ \\
\hline
\end{tabular}

*Significant differences were found with respect to the negative control.

Different letters among columns indicate significant differences $(P<0.05)$.

C- Negative control; C+Positive control.

Standard deviation ( \pm ).

Bold values indicate Highlighted results.

determined at 50\% $\left(\mathrm{LC}_{50}\right)$ and $99 \%\left(\mathrm{LC}_{99}\right)$ in addition to their 95\% confidence intervals through Probit analysis (POLO Plus, LeOra Software $\left.{ }^{\circledR}\right)(15)$.

\section{RESULTS}

\section{GIN Eclosion Inhibition by Methanolic Extracts of $D$. anisandra}

The bark methanolic extract of $D$. anisandra had a greater PEI compared to the leaf extract. Considering both the bark and leaf extracts, the material collected in the rainy season (RS) had a greater PEI compared to that collected in the dry season (DS) (Table 1). The RS extract exerted the highest activity against the three genera of nematodes, with a PEI > $90 \%$ from a concentration of $75 \mu \mathrm{g} / \mathrm{ml}$. For cyathostomins, the most notable effect was reached at $37.5 \mu \mathrm{g} / \mathrm{ml}$ (97.4\%) with the RS bark extract, which was statistically similar to the PEI of thiabendazole $(\geq 98.0 \%)(P>0.05)$, whereas for Ancylostoma caninum and Haemonchus placei, the most notable effects were reached at $75 \mu \mathrm{g} / \mathrm{ml}$, which were also statistically similar to that of thiabendazole $(\geq 97.1 \%)(P>0.05)$. The DS bark extracts had a PEI $>97 \%$ against Ancylostoma caninum and cyathostomins at $300 \mu \mathrm{g} / \mathrm{ml}$ and a PEI of $94.9 \%$ against Haemonchus placei at $600 \mu \mathrm{g} / \mathrm{ml}$. Meanwhile, the leaf extract had a PEI $\geq 90 \%$ only on cyathostomin eggs, with the RS extract exerting a greater effect $(98.7 \%$ at $150 \mu \mathrm{g} / \mathrm{ml})$ compared to the DS extract $(96.0 \%$ at $300 \mu \mathrm{g} / \mathrm{ml})$.

Overall, the lowest $\mathrm{LC}_{50}$ and $\mathrm{LC}_{99}$ were obtained with the RS bark extract $(P<0.05)$ (Table 2). Specifically, for cyathostomins, the lowest $\mathrm{LC}_{50}$ and $\mathrm{LC}_{99}$ were 11.3 and
$38.1 \mu \mathrm{g} / \mathrm{ml}$, respectively, which significantly differed from the higher lethal concentrations required by Ancylostoma caninum (60.0 and $76.7 \mu \mathrm{g} / \mathrm{ml}$, respectively) and Haemonchus placei (43.1 and $128.7 \mu \mathrm{g} / \mathrm{ml}$, respectively). Notably, the $\mathrm{LC}_{50}$ of all extracts for cyathostomins was lower than $62 \mu \mathrm{g} / \mathrm{ml}$. In contrast, the $\mathrm{LC}_{50}$ and $\mathrm{LC}_{99}$ of the RS leaf extracts, DS bark extracts and DS leaf extracts were at least two times higher for all three GINs.

\section{GIN Eclosion Inhibition by Fractions and Compounds of $\boldsymbol{D}$. anisandra}

Based on the results obtained for the crude extracts, the RS bark extract was selected for the bioguided fractionation process. The evaluation of the fractions of the partition revealed that the active fraction with the greatest efficacy (PEI) against the three nematodes was that of $n$-hexane (PEI $\geq 90 \%$ from $75 \mu \mathrm{g} / \mathrm{ml}$ ) (Table 3). Also, the residual methanol fraction at $600 \mu \mathrm{g} / \mathrm{ml}$ had a PEI of $86.6 \%$ and $59.7 \%$ against Ancylostoma caninum and Haemonchus placei, respectively. Against cyathostomins, the residual methanolic fraction and ethyl acetate showed a PEI $\geq$ $80 \%$ at $150 \mu \mathrm{g} / \mathrm{ml}$.

Similarly, the $n$-hexane fraction had the highest efficacy $(P<$ 0.05 ) according to the $\mathrm{LC}_{50}$ and $\mathrm{LC}_{99}$ values $(3.1$ to $62.1 \mu \mathrm{g} / \mathrm{ml}$ and 22.2 to $133.9 \mu \mathrm{g} / \mathrm{ml}$, respectively). The lethal concentrations obtained with the ethyl acetate and residual methanol fractions were at least six times higher.

The sub-fractionation of the $n$-hexane fraction showed that sub-fraction 5 had the greatest anthelmintic activity (Table 3). At $18 \mu \mathrm{g} / \mathrm{ml}$, sub-fraction 5 had a PEI of 95.6, 89.8, and $96.7 \%$ against Ancylostoma caninum, Haemonchus placei, and cyathostomins, respectively. The remaining sub-fractions 
TABLE 2 | Lethal concentrations at 50\% and 99\% ( $\mu \mathrm{g} / \mathrm{ml})$ and confidence intervals (95\%) of the methanolic extracts of Diospyros anisandra against eggs of Ancylostoma caninum, Haemonchus placei and cyathostomins.

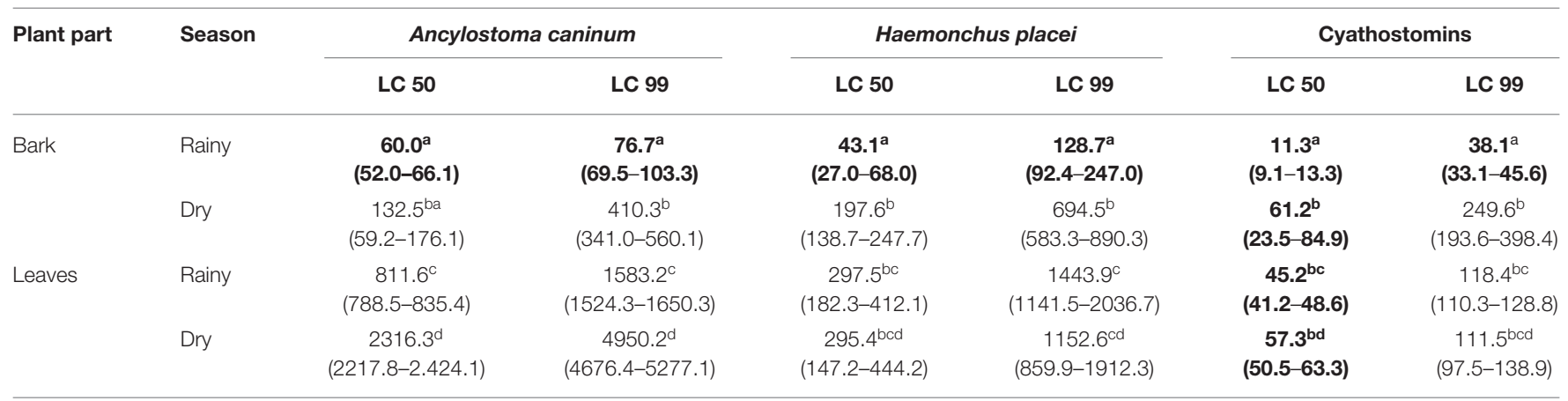

Different letters among columns indicate significant differences $(P<0.05)$.

Bold values indicate Highlighted results.

TABLE 3 | Average percentages of eclosion inhibition and 50\% and $99 \%$ lethal concentrations ( $95 \%$ confidence intervals) of the products obtained from the bioguided fractionation against eggs of Ancylostoma caninum, Haemonchus placei and cyathostomins.

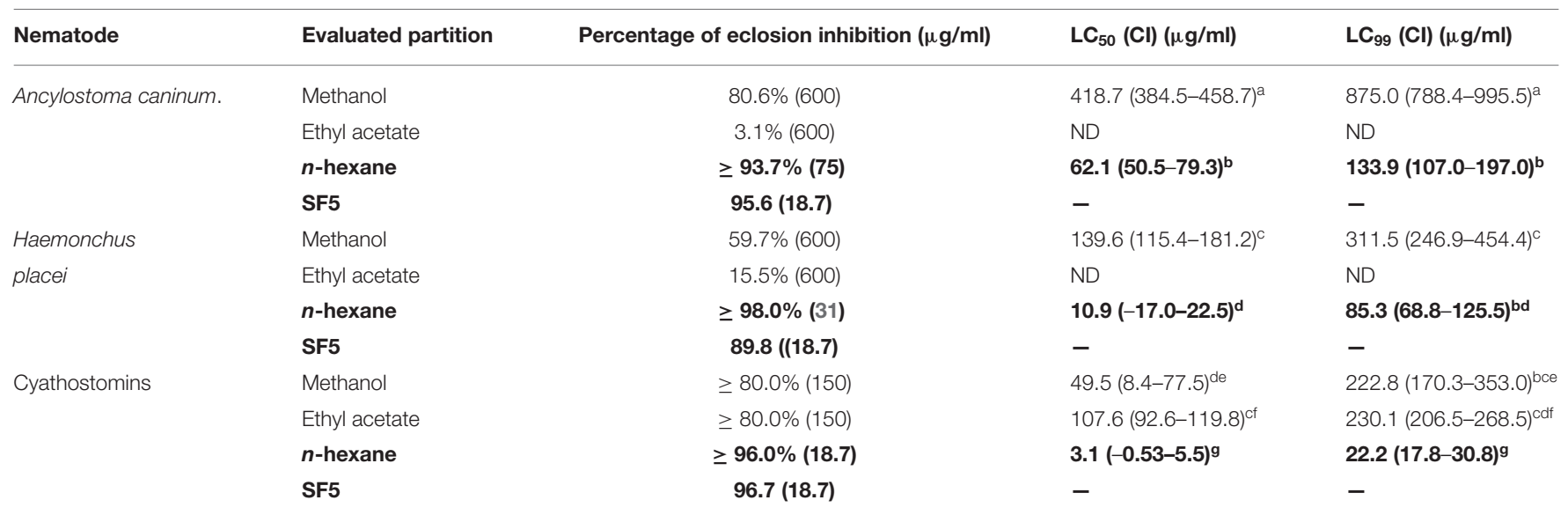

SF5, active sub-fraction 5. Cl: confidence intervals.

The $L C_{50}$ and $L C_{99}$ of sub-fraction 5 could not be determine due to the high percentages of eclosion inhibition obtained at low concentrations.

Bold values indicate Highlighted results.

Different letters among columns indicate significant differences $(P<0.05)$.

obtained a PEI of 5.9 to $11.8 \%$ against Ancylostoma caninum, 5.7 to $14.0 \%$ against Haemonchus placei and 3.3 to $18.2 \%$ against cyathostomins.

Gas chromatography-mass spectrometry revealed that the major constituent present in sub-fraction 5 was plumbagin (72.69\% abundance). This compound was evaluated against the three nematode genera, obtaining a PEI $\geq 91 \%$ at $2.3 \mu \mathrm{g} / \mathrm{ml}$. The $\mathrm{LC}_{50}$ and $\mathrm{LC}_{99}$ of sub-fraction 5 and its active compounds could not be determined because of the high PEI ( $\geq 90 \%$ ) reached at all evaluated concentrations (150 to $2.3 \mu \mathrm{g} / \mathrm{ml})$. In addition, the constituents betulin and lupeol found in the bark of $D$. anisandra (Table 4) were evaluated. These had low activity against the eggs of Ancyolostoma caninum (PEI of 3.6 and 3.2\%, respectively), Haemonchus placei (PEI of 1.4 and 1.9\%), and cyathostomins (PEI 5.0 and $5.3 \%$ ) at $2.3 \mu \mathrm{g} / \mathrm{ml}$. Even at the highest evaluated concentration $(150 \mu \mathrm{g} / \mathrm{ml})$, low PEIs were even observed against the eggs of Ancylostoma caninum (5.0 and $3.1 \%)$, Haemonchus placei (4.3 and 1.5\%), and cyathostomins (8.8 and $5.5 \%)$.
TABLE 4 | Average percentages of eclosion inhibition of the major constituents of the bark of Diospyros anisandra on Ancylostoma caninum, Haemonchus placei and cyathostomins (at a concentration of $2.3 \mu \mathrm{g} / \mathrm{ml}$ ).

Compound Ancylostoma caninum. Haemonchus placei Cyathostomins

\begin{tabular}{lccc}
\hline Plumbagin & $\mathbf{9 1 . 3}(\mathbf{0 . 8 )}$ & $\mathbf{9 2 . 6 ( 1 . 4 )}$ & $\mathbf{9 2 . 4}(\mathbf{2 . 4})$ \\
Betulin & $3.6(0.3)$ & $1.4(0.8)$ & $5.0(1.5)$ \\
Lupeol & $3.2(1.0)$ & $1.9(1.2)$ & $5.3(0.9)$
\end{tabular}

Bold values indicate Highlighted results.

\section{Ovicidal Effect of Extracts, Fractions and Major Constituents of $D$. anisandra}

The methanolic extracts of $D$. anisandra bark from the RS in addition to the hexanic fraction, sub-fraction 5 and plumbagin contained within produced an ovicidal effect on the eggs of the evaluated nematodes. Inhibition of larval development was observed: After the incubation period, the 

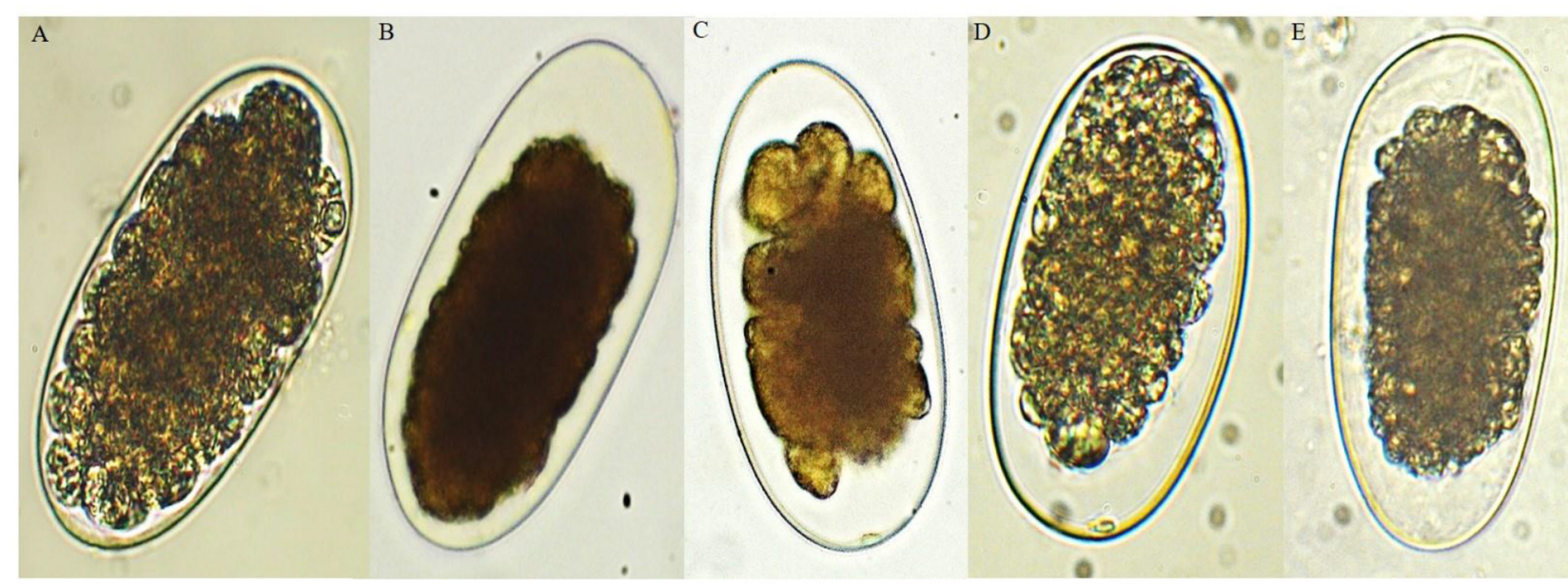

FIGURE 1 | Ovicidal effect of the bark extract of $D$. anisandra collected during the rainy season (40x): (A) negative control with developing morula, (B) positive control, (C) Ancylostoma caninum, (D) Haemonchus placei, and (E) cyathostomins.

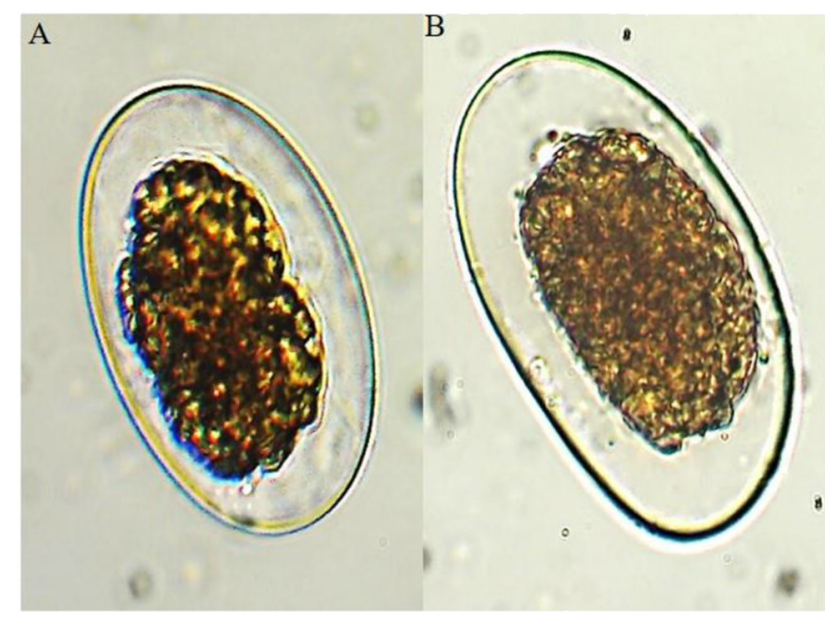

C

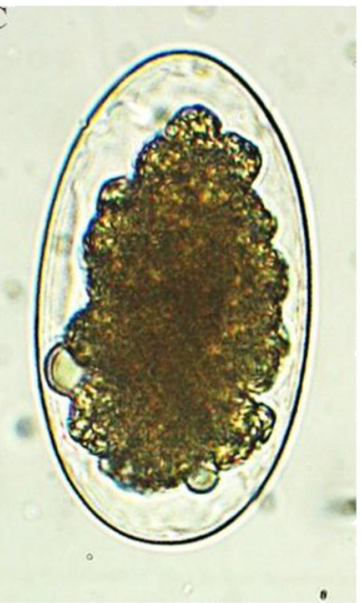

FIGURE 2 | Ovicidal effect of plumbagin on eggs of the evaluated gastrointestinal nematodes (40x): (A) Ancylostoma caninum, (B) Haemonchus placei, and (C) cyathostomins.

morula of the eggs exposed to the extract showed signs of degeneration and a dehydrated appearance (Figure 1) $(15,28)$. Specifically, the RS bark extract had a percentage of ovicidal activity (POA) of 92.5, 90.0, and $95.5 \%$ at $75 \mu \mathrm{g} / \mathrm{ml}$ against the eggs of Ancylostoma caninum, Haemonchus placei and cyathostomins, respectively. At $37.5 \mu \mathrm{g} / \mathrm{ml}$, it also had a high POA (92.9\%) against cyathostomins. On the other hand, the DS bark extract reached a POA $\geq 86 \%$ at $600 \mu \mathrm{g} / \mathrm{ml}$ against Haemonchus placei and at $300 \mu \mathrm{g} / \mathrm{ml}$ against Ancylostoma caninum; against cyathostomins, a POA of $94.2 \%$ was reached at $300 \mu \mathrm{g} / \mathrm{ml}$. Using the DS bark extract, a concentration three times was required to reach the same POA as the RS bark extract.

The POAs of the leaf extracts against Ancylostoma caninum were lower than $22 \%$ independently of the collection season. Against Haemonchus placei, a POA $\geq 50 \%$ was observed at
$300 \mu \mathrm{g} / \mathrm{ml}$ of the leaf extracts from both seasons. However, against cyathostomins, a higher POA of $97.8 \%$ was recorded with the RS leaf extract $(150 \mu \mathrm{g} / \mathrm{ml})$ and $94.2 \%$ with the DS leaf extract $(300 \mu \mathrm{g} / \mathrm{ml})$.

The hexane fraction, fraction 5 and plumbagin only exerted an ovicidal effect on treated eggs, so the reported PEIs (Tables 3, 4) also reflect the ovicidal effect (Figure 2). With the hexane fraction, a POA of 93.7 and $98 \%$ was observed at $75 \mu \mathrm{g} / \mathrm{ml}$ against eggs of Ancylostoma caninum and Haemonchus placei, respectively; against cyathostomins, a similar POA (96.0\%) was obtained at $18.7 \mu \mathrm{g} / \mathrm{ml}$. Notably, sub-fraction 5 had a POA of 95.6, 89.8, and 96.7\% against Ancylostoma caninum, Haemonchus placei and cyathostomins, respectively, at $18.7 \mu \mathrm{g} / \mathrm{ml}$. At only $2.3 \mu \mathrm{g} / \mathrm{ml}$, plumbagin had a POA of 91.3, 92.6, and 92.4\% against Ancylostoma caninum, Haemonchus placei and cyathostomins, respectively. 


\section{DISCUSSION}

Different plants of the genus Diospyros (family Ebenaceae) have been used in traditional medicine because of their high biological activity, including their antioxidant, antiinflammatory, antipyretic, analgesic, antimicrobial, antifungal, antiprotozoal and insecticidal activities (33-36). In particular, $D$. anisandra has been attributed with numerous properties, including antimicrobial activity against multi-resistant strains of Mycobacterium tuberculosis; ixodicidal activity against the tick Rhipicephalus microplus; antiviral potential against the influenza virus; and anthelmintic activity $(13-15,32,37)$.

Despite the anthelmintic potential of $D$. anisandra, previous studies have mostly focused on a single genus of GIN. So, the question remained as to whether the plant extracts of $D$. anisandra had wide-spectrum activity against two or more genera of GINs affecting different animal species. Hence, in the present study, the anthelmintic activity of $D$. anisandra was evaluated against three genera of GINs belonging to the order strongylida. Also, a modification was made to the extract dilution technique used by Arjona-Cambranes et al. (16) and Flota-Burgos et al. (15), adding 5\% absolute ethanol to the solvent and using an ultrasonic bath to ensure the complete dilution of the extracts and augment their activity $(38,39)$.

Arjona-Cambranes et al. (16) evaluated D. anisandra extract against Ancylostoma caninum eggs and reported that the RS bark extract had a PEI of $94.1 \%$ at $1,200 \mu \mathrm{g} / \mathrm{ml}$., whereas the DS bark extract had a $98.7 \%$ at $2,400 \mu \mathrm{g} / \mathrm{ml}$. The leaf extracts had a PEI $\geq 90 \%$ at $2,400 \mu \mathrm{g} / \mathrm{ml}$ independently of the season when plant materials were collected. In contrast, in the present study, higher PEIs were obtained for a RS bark extract 15 times less concentrated ( $\geq 95 \%$ at $75 \mu \mathrm{g} / \mathrm{ml}$ ) and a DS bark extract 6 times less concentrated ( $\geq 94 \%$ at $300 \mu \mathrm{g} / \mathrm{ml}$ ). With respect to the RS and DS leaf extracts, a low PEI (25.9 and 5.3\%, respectively) was obtained at $600 \mu \mathrm{g} / \mathrm{ml}$ against Ancylostoma caninum Notably, Arjona-Cambranes et al. (16) only used PBS as a solvent, which could have influenced the dissolution of the extracts and the obtained PEIs. Chagas (39) mentioned the importance of using suitable solvents for evaluating plant extracts in vitro, suggesting that an unsuitable solvent could be toxic to eggs, resulting in false positives and thereby masking the real effect of the extract. Meanwhile, (40) advised that the potential effects of plant extracts might be underestimated or discarded due to external factors, such as the poor dilution of extracts in unsuitable solvents, which could result in the rejection of potential alternative sources of anthelmintic agents.

The anthelmintic activity of other species of Diospyros or other representatives of the Ebenaceae family on eggs of Ancylostoma spp. has not been reported. The ethanolic extracts of Canthium manii $(1,000 \mu \mathrm{g} / \mathrm{ml})$, Mikania laevigata, M. glomerata, and Euterpe edulis $(10,000 \mu \mathrm{g} / \mathrm{ml})$ demonstrated a PEI of 90, 21.8, 25.9, and 21.1\% $(41,42)$. To obtain PEIs similar to those reported in the present study, Wabo et al. (41) required at least 10 times more concentrated. On the other hand, the bark extracts of D. anisadra have demonstrated better results than other control alternatives for Ancylostoma caninum eggs, such as mushroom extracts. Hofstätter et al. (43) reported PEIs against Ancylostoma caninum of 59.5 to $68.3 \%$ with Paecilomyces lilanicus extract, 52.2 to $53.5 \%$ with Trichoderma harzianum extract and $56.3 \%$ with Trichoderma virens extract.

Several studies have evaluated the use of plant extracts for the control of Haemonchus contortus. For instance, the acetone extract of Diospyros whyteana was evaluated against $H$. contortus eggs and was shown to have great potential for inhibiting eclosion, with a $\mathrm{LC}_{50}$ range of 73.77 to $175.2 \mu \mathrm{g} / \mathrm{ml}$, even though the PEI and the observed effect on eggs were not reported (44). Luka et al. (45) administered in vivo the ethanolic extract of D. mespiliformis to sheep and observed a 34.05 and $55.08 \%$ reduction in the excretion of $H$. contortus eggs at doses of 100,000 and $200,000 \mu \mathrm{g} / \mathrm{kg}$, respectively. Ngaradoum et al. (46) evaluated the methanolic extract of Ziziphus mucronate bark, obtaining a PEI of 40 to $50 \%$ on eggs at $4,000 \mu \mathrm{g} / \mathrm{ml}$. De JesúsMartínez al. (47) examined the methanolic extracts of Caesalpinia coraria fruits, observing high ovicidal activity and a PEI $>98 \%$ at $780 \mu \mathrm{g} / \mathrm{ml}$. Váradyová et al. (48) found that the methanolic extract of Artemisia absinthium had an ovicidal activity of $100 \%$ against eggs at $1,024 \mu \mathrm{g} / \mathrm{ml}$. Notably, in the present study, the RS bark extract of $D$. anisandra demonstrated a high PEI (95.5\% at $75 \mu \mathrm{g} / \mathrm{ml}$ ) against Haemonchus placei at lower concentrations than the previous methanolic extracts.

With respect to cyathostomins, Flota-Burgos et al. (15) evaluated the methanolic extracts of $D$. anisandra collected during the RS and DS against these parasites, reporting a PEI of $95 \%$ from $37.5 \mu \mathrm{g} / \mathrm{ml}$, similar to the results of the present study. No other species of Diospyros or member of the same family (Ebenaceae) has been reported to exert anthelmintic activity against cyathostomins. However, the anthelmintic activities of the extracts of Acacia baileyana, A. melanoxylon, A. podalyriifolia, Alectryon oleifolius, Duboisia hopwodii, Eucalyptus gomphocephala and Santalum spicatum were evaluated against cyathostomin eggs and shown to have a PEI of $100 \%$ at $1,400 \mu \mathrm{g} / \mathrm{ml}$ (49). Meanwhile, Peachey et al. (31) documented the anthelmintic activities of Acacia nilotica, Cucumis prophetarum and Allium savitum. Concentrations of $1,900 \mu \mathrm{g} / \mathrm{ml}$ were required to obtain a PEI higher than $90 \%$. In this latter study, a high PEI (96.4\%) was reported for cyathostomins at $37.5 \mu \mathrm{g} / \mathrm{ml}$, around half the concentration required to reach a similar PEI for Ancylostoma caninum and Haemonchus placei. Despite the evaluated GINs belonging to the same order (strongylida) and sharing the same basic structure of the egg membrane, there is considerable variability in the thickness, composition and vulnerability of eggs, which can explain the differing degrees of susceptibility among GINs $(50,51)$.

It is also important to highlight that the ovicidal activity of the methanolic extracts of $D$. anisandra in the present study was similar to that of thiabendazole (52). No significant differences $(P>0.05)$ were found between the PEI of the RS bark extract at $75 \mu \mathrm{g} / \mathrm{ml}$ and that of thiabendazole against Ancylostoma caninum and Haemonchus placei. In the case of cyathostomins, no significant differences $(P>0.05)$ were found between the PEI of thiabendazole and that of RS and DS bark extract from 37.5 to $300 \mu \mathrm{g} / \mathrm{ml}$, respectively, or the RS bark extract from $150 \mu \mathrm{g} / \mathrm{ml}$ and the DS leaf extract from $300 \mu \mathrm{g} / \mathrm{ml}$. These results confirm that, at the aforementioned concentrations, the 
methanolic extracts of $D$. anisandra can reach similar efficacies as a commercial anthelmintic such as thiabendazole.

Overall, with respect to the lethal concentrations of the $D$. anisandra extracts, the lowest $\mathrm{LC}_{50}$ and $\mathrm{LC}_{99}$ were obtained with the RS bark extract. These values significantly differed $(P<0.05)$ from the lethal concentrations obtained with the DS bark extract, RS leaf extract and DS leaf extract. Arjona-Cambranes et al. (16) reported a $\mathrm{LC}_{50}$ and $\mathrm{LC}_{99}$ of $500 \mu \mathrm{g} / \mathrm{ml}$ and $1,700 \mu \mathrm{g} / \mathrm{ml}$, respectively, for RS bark extract against Ancylostoma caninum, which is at least seven times higher than the values reported herein for the same extract. Specifically, a $\mathrm{LC}_{50}$ of $60.0,43.1$, and $11.3 \mu \mathrm{g} / \mathrm{ml}$ and a $\mathrm{LC}_{99}$ of $76.7,128.7$, and $38.1 \mu \mathrm{g} / \mathrm{ml}$ were found herein for Ancylostoma caninum, Haemonchus placei, and cyathostomins, respectively. Sakong et al. (44) reported a $\mathrm{LC}_{50}$ of 73.77 to $175.2 \mu \mathrm{g} / \mathrm{ml}$ against Haemonchus contortus with the acetone extract of Diospyros whyteana; this range is greater than that obtained herein with the RS bark extract of D. anisandra against Haemonchus placei, as well as against Ancylostoma caninum and cyathostomins. Meanwhile, Flota-Burgos et al. (15) documented a $\mathrm{LC}_{50}$ of $10.2 \mu \mathrm{g} / \mathrm{ml}$ with the RS bark extract of $D$. anisandra against cyathostomins, similar to the value obtained herein $\left(\mathrm{LC}_{50}\right.$ of $\left.11.3 \mu \mathrm{g} / \mathrm{ml}\right)$. In the present study, the $\mathrm{LC}_{50}$ and $\mathrm{LC}_{99}$ of the RS bark extract, RS leaf extract and DS leaf extract required for cyathostomins were the lowest of all the evaluated GINs; however, only the $\mathrm{LC}_{50}$ and $\mathrm{LC}_{99}$ of the RS bark extract were significantly lower. This agrees with the proposals of Bird and McClure (50) and Averlar et al. (51) concerning the structural differences and differential susceptibility of eggs, even in GINs of the same order.

In regard to the season when plant materials were collected, the RS extract had better results compared to the DS extract independently of the evaluated GIN. The concentration, composition and expression of active compounds can vary between species of the same genus, plant parts and development stages and can also be influenced by environmental factors $(53,54)$. Kubec and Musah (55) mentioned that the content of active compounds in plants varies depending on the climate and season of the year in which plants are collected. Valares (56) measured the flavonoid and diterpene content of the leaves and stems of Cistus ladanifer and found that these compounds were present in greater proportion in stems. Similarly, the total studied compounds were present in higher proportion in plants collected during the summer and in lesser proportion in plants collected during the winter. Ahmad and Mahmund (57) mentioned that plumbagin, the active compound of Diospyros with high biological activity, is found in greater proportion in the bark of this plant. These factors could explain the variation in PEI values and lethal concentrations obtained herein between plant parts and collection seasons.

The hexanic fraction had a higher PEI and lower $\mathrm{LC}_{50}$ and $\mathrm{LC}_{99}(p<0.05)$ compared to the ethyl acetate and methanolic fractions, indicating that non-polar compounds are responsible for the activity of the bark extract of $D$. anisandra collected during the RS (Table 3). The hexanic fraction of other plants has also been reported to contain active compounds with high biological activity. For example, Rosado-Aguilar et al. (23) observed that the hexanic fraction of Petiveria alliacea caused the $93.6 \%$ mortality of Rhipicephalus microplus larvae. Other studies have shown that the compounds responsible for the biological activity of plants of the genus Diospyros are found in low-polarity fractions. Trongsakul et al. (33) found that the hexanic fraction of $D$. variegata Kruz exhibited a significant antiinflammatory effect on rats in an induced oedema model as well as an antinociceptive and antipyretic effect. Meanwhile, BorgesArgáez et al. (13) reported the antifungal activity of the hexanic fraction of D. anisandra on Candida albicans, Aspergillus niger, and Colletotrichum gloeosporioides. Finally, Germann et al. (58) showed that the hexanic fraction of $D$. kaki lead to a notable reversion of resistance to multiple pharmaceuticals comparable to the efficacy of the positive control verapamil.

The presence of other bioactive compounds such as terpenoids, flavonoids, naphthoquinones, polyphenols, tannins, steroids, and coumarins has been reported in other plants of the genus Diospyros $(34,59,60)$. In particular, the presence of naphthoquinones, a group of highly reactive phenolic compounds, can be highlighted. These are important for the development of new agrochemical pharmaceuticals because of their broad antiparasitic effect, which has recently generated increasing research interest (61). Also, the antimicrobial, antifungal, anti-inflammatory, anticarcinogenic, antiprotozoal and acaricidal activities of Diospyros have been attributed to the presence of the 1,4-naphthoquinones, specifically plumbagin $(13,32,62-64)$.

Fetterer and Fleming (65) evaluated the activity of plumbagin on $H$. contortus and Ascaris suum and found that it inhibited $100 \%$ of the motility of $\mathrm{L}_{1}$ larvae at a concentration of $10.0 \mu \mathrm{g} / \mathrm{ml}$; however, only $44 \%$ of egg eclosion was inhibited, with nonhatched eggs being observed as partially embryonated. Likewise, plumbagin was found to cause the death of larvae $\left(\mathrm{L}_{1}\right.$ to $\mathrm{L}_{4}$ ) and adults of Caenorhabditis elegans exposed to $100 \mu \mathrm{g} / \mathrm{ml}$ for $24 \mathrm{~h}$. Exposure to plumbagin $(25$ and $50 \mu \mathrm{g} / \mathrm{ml}$ ) also had an adverse effect on the fertility of females, decreasing up to $80 \%$ the average number of eggs laid and the further development of larvae. Against eggs, plumbagin inhibited 95\% of eclosion at $100 \mu \mathrm{g} / \mathrm{ml}$; however, it did not present a complete ovicidal effect since eggs were still found in several stages of development, including eggs containing $\mathrm{L}_{1}$ larvae (66). These results differ from those of the present study in which plumbagin had a PEI higher than $90 \%$ from $2.3 \mu \mathrm{g} / \mathrm{ml}$ against the three evaluated genera of GINs and also exerted a notable ovicidal effect on treated eggs. However, it is worth noting that the dissolution of plumbagin in the studies of Fetterer and Fleming (65) and Chaweeborisuit et al. (66) was carried out using only DMSO, possibly influencing the results and reinforcing the importance of selecting suitable solvents for in vitro studies. Even so, Chaweeborisuit et al. (66) observed that strains of $C$. elegans resistant to levamisole, albendazole and ivermectin presented $100 \%$ mortality after exposure to $100 \mu \mathrm{g} / \mathrm{ml}$ of plumbagin for $24 \mathrm{~h}$, reinforcing the potential value of plumbagin as an alternative control for GINs resistant to current anthelmintics.

Other major compounds found in the bark of $D$. anisandra are the triterpenes betulin and lupeol (32). Betulin and its derivatives have been shown to have anti-inflammatory, antimicrobial, 
antiviral, antifungal, antimalarial, anticarcinogenic and anthelmintic activity (67-73). However, in the present study, betulin had a low PEI against the three evaluated genera of GINs $(\leq 5.0 \%)$. Meanwhile, lupeol has been shown to have anti-inflammatory, antitumoral, antimicrobial and antiprotozoal activity (74-77). However, lupeol similarly had a low PEI against the three evaluated GINs ( $\leq 5.3 \%)$.

Similar to the methanolic extracts, the products obtained from the bioguided fractionation of $D$. anisandra herein, including plumbagin, had an ovicidal effect on the eggs of the three evaluated GINs. This finding agrees with the reports of ArjonaCambranes et al. (16) and Flota-Burgos et al. (15), who also evaluated the ovicidal effects of $D$. anisandra extract on the eggs of Ancylostoma caninum and cyathostomins. It is important to note that several studies evaluating anthelmintic activity do not make a distinction between the type of effect observed, whether ovicidal or causing $\mathrm{L}_{1}$ larvae failing eclosion. However, their data are still valuable and enable us to better understand how the active compounds of $D$. anisandra extract exert their effects. The observed ovicidal effect suggests that the plumbagin present in the extract is capable of penetrating the membrane of a high proportion of treated eggs, damaging the morula and halting the development of larvae $(40,78)$. From $2.3 \mu \mathrm{g} / \mathrm{ml}$, plumbagin had a similar PEI as that obtained with thiabendazole against the three evaluated GINs. Although the concentrations of the D. anisandra extracts that obtained a PEI similar to thiabendazole are higher than the discriminating dose, GIN resistance to benzimidazoles has been widely reported. Hence, the extracts of D. anisandra and plumbagin are a potential control alternative with a similar efficacy to commercially available anthelmintics. Due to their strong anthelmintic activity, future studies should examine the mechanisms of action of the methanolic extracts of $D$. anisandra and plumbagin against GIN eggs within the order strongylida and carry out in vivo evaluations.

In conclusion, the bark extract of $D$. anisandra collected in the rainy season had the highest anthelmintic activity against eggs of Ancylostoma caninum, Haemonchus placei

\section{REFERENCES}

1. Corning S. Equine cyathostomins: a review of biology, clinical significance and therapy. Parasite Vectors. (2009) 2(Suppl. 2):S1 doi: 10.1186/1756-3305-2-S2-S1

2. Weese SJ, Peregrine SA, Anderson CEM, Fulford BM. Parasitic Diseases in: Companion Animal Zoonoses. Weese SJ, Fulford Ames M, editors. Iowa: Blackwell Publishing Ltd (2011), 3-108. doi: 10.1002/9780470958 957.ch1

3. Craig TM. Gastrointestinal nematodes, diagnosis and control. Vet Clin Food Anim. (2018) 34:185-99. doi: 10.1016/j.cvfa.2017.10.008

4. Saeed M, Beveridge I, Abbas G, Beasley A, Bauiquer J, Wilkes E, et al. Systematic review of gastrointestinal nematodes of horses from Australia. Parasite Vectors. (2019) 12:188 doi: 10.1186/s13071-019-3445-4

5. Kopp SR, Coleman GT, McCarthy JS, Kotze AC. Application of in vitro anthelmintic sensitivity assays to canine parasitology: Detecting resistance to pyrantel in Ancylostoma caninum. Vet Parasitol. (2008) 152:284-293. doi: 10.1016/j.vetpar.2007.12.020

6. Ramos F, Portella LP, Rodrigues FS, Reginato CZ, Pötter L, Cezar AS, et al. Anthelmintic resistance in gastrointestinal nematodes of beef cattle in the state and cyathostomins. Plumbagin was demonstrated to be the active compound responsible for the anthelmintic activity and ovicidal effect of D. anisandra. Because of its wide-spectrum anthelmintic activity, $D$. anisandra extract could be a potential alternative control of different genera of GINs given the current scenario of anthelmintic resistance.

\section{DATA AVAILABILITY STATEMENT}

All datasets presented in this study are included in the article/supplementary material.

\section{AUTHOR CONTRIBUTIONS}

JR-A, RR-V, RB-A, and GF-B proposed the study framework, designed and developed the experiment and analyzed the results. CM-O-M and MG-A participated in the experimental design and monitored the progress of the study. All authors participated in the writing of the manuscript.

\section{FUNDING}

The present study was financed by the National Council for Science and Technology (Consejo Nacional de Ciencia y Tecnología [CONACYT]) of Mexico through the basic science project CB-2012-01-178216.

\section{ACKNOWLEDGMENTS}

Thanks are extended to the National Council for Science and Technology (CONACYT) for the scholarship provided to GF-B for carrying out her doctoral studies. Special thanks to the technicians Mirbella Caceres Farfán and Mari Juárez Méndez for their support during plant material processing, extraction and GC/MS analysis.

of Rio Grande do Sul, Brazil. Int J Parasitol Drugs Drug Resist. (2016) 6:93-101. doi: 10.1016/j.ijpddr.2016.02.002

7. Jaeger LH, Carvalho-Costa FA. Status of benzimidazole resistance in intestinal nematode populations of livestock in Brazil: a systematic review. BMC Vet Res. (2017) 13:358. doi: 10.1186/s12917-017-1282-2

8. Van Wyk JA, Stenson MO, Van Der Merwe JS, Vorster RJ, Viljoen PG. Anthelmintic resistance in South Africa: Surveys indicate an extremely serious situation in sheep and goat farming. Onderstepoort J. Vet. (1999) 66: 273-284.

9. Canever R, Braga P, Boeckh A, Grycajuck M, Bier D, Molento M. Lack of,Cyathostomin sp. reduction after anthelmintic treatment in horses in Brazil. Vet Parasitol. (2013) 194:35-9. doi: 10.1016/j.vetpar.2012. 12.020

10. Chaparro JJ, Villar D, Zapata JD, López S, Howell S, López A, et al. Multi-drug resistant Haemonchus contortus in a sheep flock in Antioquia, Colombia. Vet Parasitol Reg Stud Reports. (2017) 10:29-34. doi: 10.1016/j.vprsr.2017.07.005

11. Kitchen S, Ratnappan R, Han S, Leasure C, Grill E, Iqbal Z, et al. Isolation and characterization of a naturally occurring multidrug-resistance strain of the canine hookworm, Ancylostoma caninum. Int J Parasitol. (2019) 49:397-406. doi: 10.1016/j.ijpara.2018.12.004 
12. Fabricant DS, Farnsworth NR. The value of plants used in traditional medicine for drug discovery. Environ Health Perspect. (2001) 109:69-75. doi: 10.1289/ehp.01109s169

13. Borges-Argáez R, Canché-Chay CI, Peña-Rodríguez LM, Said-Fernández S, Molina-Salinas GM. Antimicrobial activity of Diospyros anisandra. Fitoterapia. (2007) 78:370-2. doi: 10.1016/j.fitote.2007.03.004

14. Rosado-Aguilar JA, Aguilar-Caballero AJ, Rodríguez-Vivas RI, BorgesArgaez R, García-Vázquez Z, Méndez-González M, et al. Actividad ixodicida de extractos crudos de Diospyros anisandra contra larvas de Rhipicephalus (Boophilus) microplus (Acari: ixodidae). Tropical and Subtropical Agroecosystems. (2008) 8:297-301. Available online at: https:// www.redalyc.org/articulo.oa?id=93911235009

15. Flota-Burgos GJ, Rosado-Aguilar JA, Rodríguez-Vivas RI, Arjona-Cambranes KA. Anthelminthic activity of methanol extracts of Diospyros anisandra and Petiveria alliacea on cyathostomin (Nematoda: Cyathostominae) larval development and egg hatching. Vet Parasitol. (2017) 248:74-79. doi: 10.1016/j.vetpar.2017.10.016

16. Arjona-Cambranes KA, Rosado-Aguilar JA, Rodríguez-Vivas RI, OrtegaPacheco A, Flota-Burgos GJ. Actividad antihelmíntica in vitro de extractos vegetales contra huevos de Ancylostoma spp. de perros Ciencia y Agricultura. Tunja:Universidad Pedagógica y Tecnológica de Colombia (2016) 13: 76.

17. Instituto Nacional de Estadística y Geografía (INEGI). Conociendo Yucatán. (2013). Available online at: http://internet.contenidos.inegi. org.mx/contenidos/productos/prod_serv/contenidos/espanol/bvinegi/produ ctos/estudios/conociendo/YUCATAN.pdf (accessed February 17, 2020).

18. Ankli A, Heinrich M, Bork P, Wolfram L, Bauerfeind P, Brun R, et al. Yucatec Mayan medicinal plants: Evaluation based on indigenous uses. J. Ethnopharmacol. (2002) 79:43-52. doi: 10.1016/S0378-8741(01)00355-5

19. Duran R, Torres JCT, Manríquez GI. Endemic phytotaxa of the Peninnsula of Yucatan. Harvard Pap Bot. (1998) 3:263.

20. Rodriguez-Sanchez PV, Tacher SIL, Ramirez-Marcial N, Estrada-Lugo E. Comparative analysis of fundo legal vegetation and mature vegetation in the town of Yaxcaba, Yucatán, México. Botanic Sci. (2019) 97:50-64 doi: $10.17129 /$ botsci.2024

21. García GG, Sosa EJ. Ordenamiento territorial del estado de Yucatán. Ed. Yucatán: Universidad Autónoma de Yucatán (2013) 13-28.

22. Flores S, Durán R, Ortíz J. Comunidades Vegetales Terrestres. En: Durán R. Méndez M (eds) Biodiversidad y desarrollo humano en yucatán. CICY, PPD-FMAM, CONABIO, SEDUMA, Yucatán, págs (2010), 125-9.

23. Rosado-Aguilar JA, Aguilar-Caballero A, Rodriguez-Vivas RI, Borges-Argaez R, Garcia-Vazquez Z, Mendez-Gonzalez M. Acaricidal activity of extracts from Petiveria alliacea (Phytolaccaceae) against the cattle tick, Rhipicephalus (Boophilus) microplus (Acari: ixodidae). Vet Parasitol. (2010) 168:299-303. doi: 10.1016/j.vetpar.2009.11.022

24. Rodríguez-Vivas RI, Cob-Galera LA. Técnicas Diagnósticas En Parasitología Veterinaria, $2^{a}$ edición. Universidad Autónoma de Yucatán (2005). p. 32-59.

25. Bowman D, and Georgis' Parasitology for Veterinarians. 10th edition. Saunders, (2013) 496.

26. Woellner Santosa D, Madeira de Carvalhob LM, Beltrão Molento. M. Identification of third stage larval types of cyathostomins of equids: An improved perspective. Vet Parasitol. (2018) 260:49-52. doi: 10.1016/j.vetpar.2018.08.007

27. Zajac MA, y Conboy GA, Veterinary Clinical, Parasitology. and $8^{\mathrm{a}}$ ed. USA.American Association of Veterinary Parasitologist. (2012), 37.

28. Vargas-Magaña JJ, Torres-Acosta JFJ, Aguilar-Caballero AJ, Sandoval-Castro CA, Hoste H, Chan-Pérez JI. Anthelmintic activity of acetone-water extracts against Haemonchus contortus eggs: interactions between tannins and other plant secondary compounds. Vet Parasitol. (2014) 206:322-7. doi: 10.1016/j.vetpar.2014.10.008

29. Chan-Pérez JI, Torres-Acosta JFJ, Sandoval-Castro CA, Hoste H, CastañedaRamírez GS, Vilarem G, et al. In vitro susceptibility of ten Haemonchus contortus isolates from different geographical origins towards acetone: water extracts of two tannin rich plants. Vet Parasitol. (2016) 217:53-60. doi: 10.1016/j.vetpar.2015.11.001

30. Coles GC, Jackson F, Pomroy WE, Prichard RK, von Samson-Himmelstjerna G, Silvestre A, et al. The detection of anthelmintic resistance in nematodes of veterinary importance. Vet Parasitol. (2006) 135:167-85. doi: 10.1016/j.vetpar.2005.11.019
31. Peachey LE, Pinchbeck GL, Matthews JB, Burden FA, Mulugeta G, Scantlebury $\mathrm{CE}$, et al. An evidence-based approach to the evaluation of ethnoveterinary medicines against strongyle nematodes of equids. Vet Parasitol. (2015) 210:40-52. doi: 10.1016/j.vetpar.2015.03.009

32. Uc-Cachón AH, Borges-Argáez R, Said-Fernández S, Vargas-Villarreal J, González-Salazar F, Méndez-González M, et al. Naphthoquinones isolated from Diospyros anisandra exhibit potent activity against pan-resistant firstline drugs Mycobacterium tuberculosis strains. Pulm Pharmacol Ther. (2014) 21:114-20. doi: 10.1016/j.pupt.2013.08.001

33. Trongsakul S, Panthong A, Kanjanapothi D, Taesotikul T. The analgesic, antipyretic and anti-inflammatory activity of Diospyros variegata Kruz, J. Ethnopharmacol. (2003) 85:221-5. doi: 10.1016/S0378-8741(03)00020-5

34. Ganapaty S, Thomas PS, Fotso S, Laatsch H. Antitermitic quinones from Diospyros sylvatica. Phytochemistry. (2004) 65:1265-71. doi: 10.1016/j.phytochem.2004.03.011

35. Gao H, Cheng N, Zhou J, Wang B, Deng J, Cao W. Antioxidant activities and phenolic compounds of date plum persimmon (Diospyros lotus L.) fruits. $J$ Food Sci Technol. (2014) 51:950-6. doi: 10.1007/s13197-011-0591-x

36. Rauf A, Uddinb G, Patelc S, Khand A, Halime SA, Bawazeerg S, et al. Diospyros, an under-utilized, multi-purpose plant genus: a review. Biomed Pharmacother. (2017) 91:714-30. doi: 10.1016/j.biopha.2017.05.012

37. Cetina-Montejo L, Ayora-Talavera G, Borges-Argáez R. Zeylanone epoxide isolated from Diospyros anisandra stem bark inhibits influenza virus in vitro. Arch Virol. (2020) 164:1543-52. doi: 10.1007/s00705-019-04223-y

38. Liu Z. Preparation of botanical samples for biomedical research. Endrocr Metab Inmune Disord Drugs Target. (2008) 8:112-21. doi: $10.2174 / 187153008784534358$

39. Chagas AC. Medicinal plant extracts and nematode control. CAB Rev. (2015) 10:1-8. doi: 10.1079/PAVSNNR201510008

40. D’Angelo F, Poné JW, Yondo J, Komtangi MC, Vittori S, Mbida M. Evaluation of ovicidal and larvicidal activities of methylene chloride extract of Annona senegalensis (Annonaceae) stem bark on Heligmosomoides bakeri (Nematoda, Heligmosomatidae). Global J Sci Front Res. (2014) 14:21-39. doi: 10.4172/2327-5162.S1.009

41. Wabo Pon,é J, Bilong Bilong CF, Mpoame M, Fusi Ngwa C, Coles GC. In vitro activity of ethanol, cold water and hot water extracts of the bark of Canthium mannii (Rubiaceae) stem on Ancylostoma caninum eggs. East and Central Afr J Pharm Sci. (2006) 9:14-28. doi: 10.4314/ecajps.v9i 1.9731

42. Tonini Zamprogno T, Garcia Lopes AC, Lacerda T, Hiura E, Abreu da Fonseca L, Senna T, et al. Activity of euterpene edulis martius, mikania glomerata spreng, and mikania laevigata schultz bip. Extracts on gastrointestinal nematodes Toxocara canis and Ancylostoma caninum. Arch Clin Infect Dis. (2015) 10:e27495. doi: 10.5812/archcid.27495

43. Hofstätter BDM, Oliveira da Silva Fonseca A, de Souza Maia Filho F, de Souza Silveira J, Persici BM, Pötter L, et al. Effect of Paecilomyces lilacinus, Trichoderma harzianum and Trichoderma virens fungal extracts on the hatchability of Ancylostoma eggs. Revista Iberoamericana de Micología. (2017) 34:28-31. doi: 10.1016/j.riam.2016. 04.004

44. Sakong BM, Adamu M, Eloff JN, Ahmed AS, Naidoo V, McGaw LJ. Pharmacological investigations of six medicinal plants used traditionally in southern Africa to treat gastrointestinal nematode infections of small ruminants. Planta Med. (2016) 81:S1-381. doi: 10.1055/s-0036-15 96976

45. Luka J, Mbaya AW, Biu AA, Nwosu CO. The effect of Diospyros mespiliformis (Ebenaceae) extracts on the haemato-biochemical parameters of Yankasa Sheep experimentally infected with Haemonchus contortus. Nigerian J. Parasitol. (2017) 38:271-7. doi: 10.4314/njpar.v38i2.26

46. Ngaradoum O, Kagira JM, Karanja SM, Kipyegon C, Maina N. In vitro ovicidal and larvicidal activity of aqueous and methanolic extracts of Ziziphus mucronata barks against Haemonchus contortus. Eur J Exp Biol. (2017) 7:1-6. doi: 10.21767/2248-9215.100001

47. De Jesús-Martínez X, Olmedo-Juárez A, Olivares-Pérez J, Zamilpa A, Mendoza de Gives $\mathrm{P}$, López-Arellano $\mathrm{ME}$, et al. In vitro anthelmintic activity of methanolic extract from Caesalpinia coriaria J. Willd fruits against Haemonchus contortus eggs and infective larvae. Biomed Res Int. (2018). p. 1-6. doi: 10.1155/2018/7375693 
48. Váradyová Z, Pisarč́íková J, Babják M, Hodges $\mathrm{A}$, Mravč́áková D, Kišidayová $\mathrm{S}$, et al. Ovicidal and larvicidal activity of extracts from medicinalplants against Haemonchus contortus. Exp Parasitol. (2018) 195:71-7. doi: 10.1016/j.exppara.2018.10.009

49. Payne SE, Kotze AC, Durmic Z, Vercoe PE. Australians plants show anthelmintic activity toward equine cyathostomins in vitro. Vet Parasitol. (2013) 1:153-60. doi: 10.1016/j.vetpar.2013.01.012

50. Bird A, McClure MA. The tylenchid (Nematoda) egg shell: structure, composition and permeability. Parasitology. (1976) 72:19-28. doi: 10.1017/S0031182000058431

51. Avelar TS, Lopes EA, Evans HC, Grassi de Freitas L. Interactions between Pochonia chlamydosporia and nematodes. In: Perspectives in sustainable nematode management through Pochonia chlamydosporia applications for root and rhizosphere health, eds. Manzanilla-López RH. Lopez-Llorca (Cham LV, Switzerland: Springer), 77-98. doi: 10.1007/978-3-319-59224-4_4

52. Mendoza PN. Farmacología Médica. Ciudad de México: Editorial Médica Panamericana (2008). p. 687-94.

53. Gobbo-Neto L, Lopes NP. Plantas medicinais: fatores de influência no conteúdo de metabólitos secundários. Química Nova. (2007) 30:374-81. doi: 10.1590/S0100-40422007000200026

54. Castelo AVM, Del Menezzi CHS, Resck IS. Seasonal variation in the yield and the chemical composition of essential oils from two brazilian native arbustive species. J Applied Sci. (2012) 12:753-60. doi: 10.3923/jas.2012.753.760

55. Kubec R, Musah RA. Cysteine sulfoxide derivatives in Petiveria alliacea. Phytochemistry. (2001) 58:981-5. doi: 10.1016/S0031-9422(01)00304-1

56. Valares Masa C. Variación Del Metabolismo Secundario en Plantas Debida al Genotipo y al Ambiente. Badajoz: Universidad de Extremadura (2011), 105-108.

57. Ahmad AH, Mahmud HF. Pharmacological activities of Diospyros mespiliformis: a review. Int J Pharm Biol Sci. (2017) 7:93-6. Available online at: https://www.ijpbs.com/ijpbsadmin/upload/ijpbs_5a27d6789d499. pdf

58. Germann UA, Pastan I, Gottesman MM. P-Glycoproteins: mediators of multidrug resistance. Semin Cell Biol. (1993) 4:63-76. doi: 10.1006/scel.1993.1008

59. Adeniyi BA, Odetola HA, Oso BA. Antimicrobial potentials of Diospyros mespiliformis (Ebenaceae). Afr J Med Sci. (1996) 25:221-4.

60. Mallavadhani UV, Panda AK, Rao R. Pharmacology and chemotaxonomy of Diospyros. Phytochemistry. (1998) 49:901-51. doi: 10.1016/S0031-9422(97)01020-0

61. Xiao-Fei S, Ying-Qian L, Xiao G, Xiao-Lou M, Cheng C, Jun-Xiang Z, et al. Application of sustainable natural resources in agriculture: acaricidal and enzyme inhibitory activities of Naphthoquinones and their analogs against Psoroptes cuniculi. Sci Rep. (2018) 8:1609. doi: 10.1038/s41598-018-19964-0

62. Sumsakul W, Plengsuriyakarn T, Chaijaroenkul W, Viyanant V, Karbwang J, Na-Bangchang K. Antimalarial activity of plumbagin in vitro and in animal models. BMC Complement Altern. Med. (2014) 14:1-6. doi: 10.1186/1472-6882-14-15

63. Awasthi BP, Kathuria M, Pant G, Kumari N, Miltra K. Plumbagin, a plant-derived naphthoquinone metabolite induces mitochondria mediated apoptosis-like cell death in Leishmania donovani: an ultrastructural and physiological study. Apoptosis. (2016) 21:941-53. doi: 10.1007/s10495-016-1259-9

64. Hafeez BB, Zhong W, Fischer WJ, Mustafa A, Shi X, Meske L, et al. Plumbagin, a medicinal plant (Plumbago zeylanica)-derived 1,4-naphthoquinone, inhibits growth and metastasis of human prostate cancer PC-3M-luciferase cells in an orthotopic xenograft mouse model. Mol Oncol. (2013) 7:428-39. doi: 10.1016/j.molonc.2012.12.001

65. Ferreter RH, Fleming MW. Effects of Plumbagin on development of the parasitic nematodes Haemonchus contortus and Ascaris suum. Comp Biochem Physiol. (1991) 100:539-42. doi: 10.1016/0742-8413(91)90036-S
66. Chaweeborisuit P, Suriyonplengsaeng C, Suphamungmee W, Sobhon P, Meemon K. Nematicidal effect of plumbagin on Caenorhabditis elegans: a model for testing a nematicidal drug. Zeitschrift fur Naturforschung. C. Journal of Biosciences. (2016) 71:121-31. doi: 10.1515/znc-2015-0222

67. Steele JC, Warhurst DC, Kirby GC, Simmonds MS. In vitro and in vivo evaluation of betulinic acid as an antimalarial. Phytother Res. (1999) 13:115-9. doi: 10.1002/(SICI)1099-1573(199903)13:2<115::AID-PTR404>3.0.CO;2-1

68. Kashiwada Y, Chiyo J, Ikeshiro Y, Nagao T, Okabe H, Consentino LM, et al. Synthesis and anti-HIV activity of 3-alkylamido-3-deoxy-betulinic acid derivatives. Chem Pharm Bull. (2000) 48:1387-90. doi: 10.1248/cpb.48.1387

69. Bernard P, Scior T, Didier B, Hibert M, Berthon J. Ethnopharmacology and bioinformatic combination for leads discovery: application to phospholipase A2 inhibitors. Photochemistry. (2001) 58:865-74. doi: 10.1016/S0031-9422(01)00312-0

70. Yli-kauhaluoma J, Koskimies S, Alakurtti. S., Maekelae T, Tammela P. Betulin derived compounds useful as antibacterial agents. World Intellectual Property Organization Publ.of the Int.Appl. with int.search report WO2007FI50328 (2007).

71. Gomes DC, de Lima HG, Vaz AV, Santos NS, Santos FO, Dias ÊR, et al. In vitro anthelmintic activity of the Zizyphus joazeiro bark against gastrointestinal nematodes of goats and its cytotoxicity on Vero cells. Vet Parasitol. (2016) 226:10-6. doi: 10.1016/j.vetpar.2016.06.004

72. Vijaya, Yadav AK. In vitro anthelmintic assessment of selected phytochemicals against Hymenolepis diminuta, a zoonotic tapeworm. J Parasit Dis. (2016) 40:1082-6. doi: 10.1007/s12639-014-0560-1

73. Vijaya, Yadav AK, Gogoi S. In vitro and in vivo anthelmintic efficacy of two pentacyclic triterpenoids, ursolic acid and betulinic acid against mice pinworm, Syphacia obvelata. J Parasit Dis. (2018) 42:144-9. doi: 10.1007/s12639-017-0960-0

74. Ahamed BKM, Krishna V, Gowdru HB, Rajanaika H, Kumaraswamy HM, Rajshekarappa $\mathrm{S}$, et al. Isolation of bactericidal constituents from the steam bark of Grewia tiliaefolia Vahl. Res J Med Plan. (2007) 1:72-82. doi: $10.3923 /$ rjmp.2007.72.82

75. Saleem M, Madonni N, Zaid MA, Khan N, Hafeez B, Asim M, et al. Lupeol inhibits growth of highly aggressive human metastatic melanoma cells in vitro and in vivo by inducing apoptosis. Cancer Therapy. (2008) 14:2119-27. doi: 10.1158/1078-0432.CCR-07-4413

76. Machado VR, Sandjo LP, Pinheiro GL, Moraes MH, Steindel M, Pizzolatti MG, et al. Synthesis of lupeol derivatives and their antileishmanial and antitrypanosomal activities. Nat Prod Res. (2017) 32:275-81. doi: 10.1080/14786419.2017.1353982

77. Thirumalaisamy R, Ameen F, Subramanian A, Selvankumar T, Alwakeel SS, Govarthanan M. In-vitro and in-silico anti-inflammatory activity of Lupeol isolated from Crateva adansonii and its hidden molecular mechanism. Int $J$ Pept. Res Ther. (2020). p. 1-11. doi: 10.1007/s10989-019-10006-5

78. Souza M, Belvi C, Morais SM, Costa C, Silva A, Braz-filho R. Anthelmintic acetogenin from Annona Squamosa L. Seed An Acad Bras Cienc. (2008) 80:271-7. doi: 10.1590/S0001-37652008000200005

Conflict of Interest: The authors declare that the research was conducted in the absence of any commercial or financial relationships that could be construed as a potential conflict of interest.

Copyright (๑) 2020 Flota-Burgos, Rosado-Aguilar, Rodríguez-Vivas, Borges-Argáez, Martinez-Ortiz-de-Montellano and Gamboa-Angulo. This is an open-access article distributed under the terms of the Creative Commons Attribution License (CC BY). The use, distribution or reproduction in other forums is permitted, provided the original author(s) and the copyright owner(s) are credited and that the original publication in this journal is cited, in accordance with accepted academic practice. No use, distribution or reproduction is permitted which does not comply with these terms. 